\title{
Ketepatan Penentuan Kode Diagnosis Utama Penyebab Kematian Pada Kasus Stroke Di RSUD Brigjend H. Hasan Basry Kandangan
}

The Precision Of The Determination Of Main Diagnosis Codes Cause Of Death In The Case Of A Stroke In A Hospital Brigjend H. Hasan Basry Kandangan

\author{
Nina Rahmadiliyani ${ }^{1 *}$, Aida Fitria ${ }^{2}$ \\ ${ }^{1}$ STIKes Husada Borneo, Jl. A. Yani Km. 30,5 No.4 Banjarbaru, Kalimantan Selatan \\ ${ }^{2}$ Alumni STIKes Husada Borneo, JI. A. Yani Km. 30,5 No.4 Banjarbaru, Kalimantan Selatan \\ *korespondensi :ninaroshan.nr@gmail.com@gmail.com
}

\begin{abstract}
World Health Information (WHO) establishes a set of rules or procedures that must be followed for granting kodefikasi UCoD determination of the code on certificate of death must pay attention to the sequence of events leading to the death of the disease and the cause of the beginning of the sequence such. Some hospitals are not doing the coding causes of death and inaccuracies in coding causes of death data produces the wrong health. This research aims to know the description of accuracy determination of main diagnosis codes cause of death in the case of a stroke in a hospital Brigjend H. Hasan Basry Kandangan. This research use descriptive qualitative research methods with quantitative studies. This research was conducted with observation 68 medical record documents and interviewing doctors, koder and head installation medical record as supporting in this research. In this research note the hospital does not have an SOP and the absence of writing the cause of death on a death certificate so as not to kodefikasi the implementation and reporting of the implementation of the hospital not be RL4 about mortality reporting.
\end{abstract}

\section{Keywords : Diagnosis, Stroke, Hospital, Codes}

\section{Pendahuluan}

Stroke adalah penyakit pada otak berupa gangguan fungsi syaraf lokal atau global, munculnya mendadak, progresif, dan cepat. Gangguan fungsi syaraf pada stroke disebabkan oleh gangguan peredaran darah otak non traumatik. Gangguan syaraf terebut menimbulkan gejala antara lain kelumpuhan wajah atau anggota badan, bicara tidak lancar, bicara tidak jelas (pelo), mungkin perubahan kesadaran, gangguan penglihatan, dan lain-lain. Didefinisikan sebagai stroke jika pernah didiagnosis menderita penyakit stroke oleh tenaga kesehatan (dokter/perawat/bidan) atau belum pernah didiagnosis menderita penyakit stroke oleh nakes tetapi pernah mengalami secara mendadak keluhan kelumpuhan pada satu sisi tubuh atau kelumpuhan pada satu sisi tubuh yang disertai kesemutan atau baal satu sisi tubuh atau mulut menjadi mencong tanpa kelumpuhan otot mata atau bicara pelo atau sulit bicara atau komunikasi dan atau tidak mengerti pembicaraan (1).

Stroke merupakan penyebab kematian ketiga di dunia setelah penyakit jantung koroner dan kanker baik di negara maju maupun negara berkembang. Satu dari 10 kematian disebabkan oleh stroke. Secara global, 15 juta orang terserang stroke setiap tahunnya, satu pertiga meninggal dan sisanya mengalami kecacatan permanen. Stroke merupakan penyebab utama kecacatan yang dapat dicegah (2).

Prevalensi stroke di Indonesia berdasarkan diagnosis tenaga kesehatan sebesar 7 per mil dan yang terdiagnosis tenaga kesehatan atau gejala sebesar 12,1 per mil. Prevalensi penyakit stroke pada kelompok yang didiagnosis nakes serta yang didiagnosis nakes atau gejala meningkat seiring dengan bertambahnya umur, tertinggi pada umur $\geq 75$ tahun $(43,1 \%$ 。 dan 67,0\%०). Prevalensi stroke yang terdiagnosis nakes maupun berdasarkan diagnosis atau gejala sama tinggi pada lakilaki dan perempuan (1).

Didiagnosis nakes (16,5\%。) maupun diagnosis nakes atau gejala (32,8\%). Prevalensi stroke di kota lebih tinggi dari di desa, baik berdasarkan diagnosis nakes $(8,2 \%)$ maupun berdasarkan diagnosis 
nakes atau gejala (12,7\%o). Prevalensi lebih tinggi pada masyarakat yang tidak bekerja baik yang didiagnosis nakes $(11,4 \%$ ) maupun yang didiagnosis nakes atau gejala (18\%). Prevalensi stroke berdasarkan diagnosis atau gejala lebih tinggi pada kuintil indeks kepemilikan terbawah dan menengah bawah masing masing 13,1 dan 12,6 per mil (1).

Berdasarkan data riset kesehatan dasar, beberapa penyakit tidak menular yang menjadi penyebab kematian di Kalimantan Selatan yaitu, diabetes melitus $(2 \%$ ) dari jumlah penduduk, kemudian hipertensi mencapai $(30,8 \%$ ) , stroke $(9,2 \%)$, kanker $(1,6 \%$ ) , dan jantung koroner $(0,5 \%$ ). Sedangkan data secara riil penderita hipertensi per kabupaten dan kota di Kalsel tahun 2015 yaitu, Kota Banjarmasin merupakan tertinggi penderita hipertensi yaitu 18.730 penderita, disusul Tanah Laut sebanyak 14.121 orang penderita (1).

Data kasus stroke di Kabupaten Banjar 7.738 orang penderita, Kotabaru 6.680 orang penderita, Banjarbaru 5.629 orang penderita, Tapin 3.085 orang, Barito Kuala 2.985 orang dan sisanya berkisar antara 2.500 hingga di atas seribu orang. Sedangkan kota Banjarmasin sebanyak 283 orang dan Banjarbaru sebanyak 191 orang (3).

Klasifikasi penyakit adalah pengelompokkan penyakit-penyakit sejenis dengan ICD-10 (International Statistical Classification of Disease and Related Health Problems Tenth Revision) untuk istilah penyakit dan masalah yang berkaitan dengan kesehatan. Penegakkan dan penulisan diagnosis sesuai dengan ICD-10 merupakan tugas dan tanggung jawab dokter yang merawat pasien. Oleh karenanya, diagnosis yang ditulis dalam rekam medis harus lengkap atau tepat dan jelas sesuai dengan terminologi medis dan arahan yang ada pada buku ICD-10 (4).

Diagnosis adalah pemberian penetapan kode dengan menggunakan huruf dan angka atau kombinasi antara huruf dan angka yang mewakili komponen data. Penggunaan atau penulisan diagnosis lebih dari satu istilah medis atau terminologi medis akan menyulitkan dalam pengumpulan dan perolehan informasi morbiditas dan mortalitas yang akurat dan tepat (4).
Satu diantara kasus yang sering ditangani di rumah sakit adalah kasus kematian (Mortalitas) menggunakan kode ICD-10 dengan tabel bantu MMDS untuk menentukan penyebab kematian. Pengolahan data mortalitas dengan proses reseleksi penentuan penyebab dasar kematian $(U C O D)$ terhadap diagnosisdiagnosis yang telah tertulis pada formulir dengan jumlah sampel 83. Setelah dilakukan proses reseleksi penentuan penyebab dasar kematian (UCOD) menggunakan ICD-10 dan tabel MMDS, membandingkan antara $U C O D$ rumah sakit dan hasil pembuatan reseleksi UcoD diperoleh hasil kesesuaian sebanyak 19\% $U c o D$, sedangkan untuk ketidaksesuaian sebanyak $81 \%$. Ketidaksesuian ini karena masih banyak diagnosis henti jantung, henti napas, gagal napas, cardiac arrest, dan kondisi symtoms lainnya yang menjadi penyebab dasar kematian (Underlying Cause of Death) yang ditegakkan pada formulir sebab kematian (5).

RSUD Brigjend $\mathrm{H}$. Hasan Basry pada data tahun 2017 terdapat 68 pasien stroke yang meninggal pertahun nya dan pada kasus kematian tidak menggunakan tabel MMDS dan hanya menggunakan ICD-10. Pada survei awal yang telah diteliti pada formulir rekam medis pasien stroke dari 15 rekam medis ditemukan masih belum menggunakan tabel MMDS. Seperti pada kasus Stroke hemoregik dengan diagnosis sekunder Hipertensi dan kode yang dituliskan koder ialah 160, akan tetapi jika penyakit tersebut ditinjau menggunakan ICD-10 maka kode untuk diagnosis ini adalah 161.9 sebagai diagnosa utama yaitu stroke hemoregik dan 110 adalah diagnosa sekunder berdasarkan Tabel MMDS penyebab utama kematian adalah 161.9 yaitu stroke hemoregik. Untuk menentukan penyebab kematian, WHO menetapkan suatu himpunan prosedur atau rule yang harus diikuti untuk pemberian kodefikasi $U C o D$ penentuan kode pada sertifikat kematian harus memperhatikan kejadian penyakit menuju kematian dan penyebab awal dari urutan tersebut.

Latar belakang diatas menjadi dasar pertimbangan peneliti untuk fokus pada pertanyaan dengan rumusan masalah bagaimana gambaran pelaksanaan ketepatan penentuan kode diagnosis utama 
penyebab kematian pada kasus stroke di RSUD Brigjend H.Hasan Basry?

\section{Metode Penelitian}

Penelitian ini menggunakan metode penelitian kuantitatif didukung kualitatif. Lokasi penelitian di instalasi rekam medis. Subjek penelitian adalah dokter, koder, kepala instalasi rekam medis dan data yang diperlukan adalah 68 berkas rekam medis pasien pada kasus kematian dengan diagnosis stroke di RSUD Brigjend H. Hasan Basry Kandangan tahun 2017. Pada penelitian ini menggunakan jenis wawancara mendalam dan observasi.

Analisis data kualitatif dilakukan terhadap data empiris yang terkumpul yang berupa kumpulan kata-kata informan. Analisis data menggunakan alur dari miles dan Huberman yang terdiri dari tiga tahap, yaitu reduksi data, penyajian data, dan penarikan kesimpulan/verifikasi (6).

\section{Hasil Penelitian}

\section{Prosedur Pelaksanaan ketepatan penentuan penyebab utama kematian}

Berdasarkan hasil observasi dalam menetapkan penyebab utama kematian tidak berpedoman pada Standar Operasional Prosedur (SOP) dan pada sertifikat kematian tidak adanya pencantuman penyebab kematian sehingga pada saat menentukan penyebab kematian pasien, dokter hanya menuliskan pada resume pasien keluar.

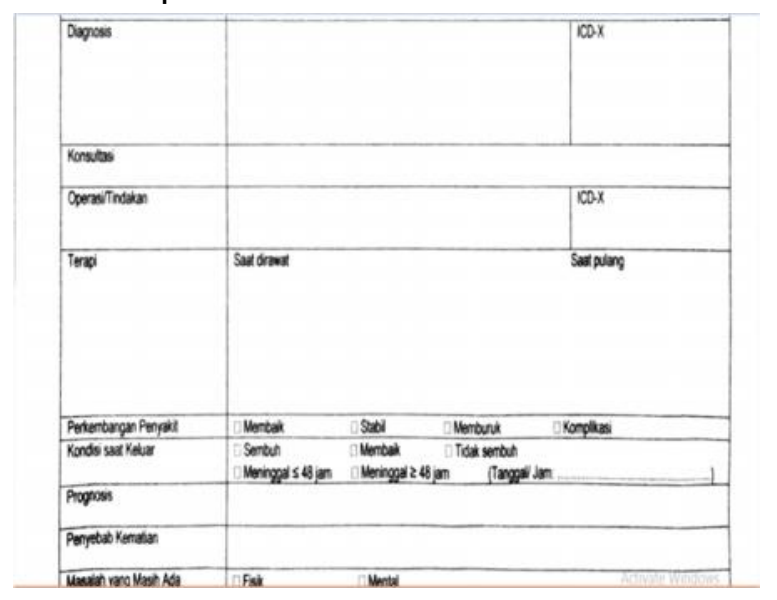

Penulisan diagnosis penyebab kematian dicantumkan pada resume pasien keluar seperti pada gambar di bawah :

Berdasaran hasil observasi pada formulir RM 17 yaitu resume pasien keluar, dokter biasanya menuliskan penyebab kematian pada kolom resume pasien keluar tepat di samping kolom penyebab kematian pada gambar diatas dengan penulisan Penyebab Kematian : Herniasi otak dan Penyebab Kematian: (-) dengan tanda strip jika dokter tidak menuliskan penyebab kematian. Jika dokter tidak menuliskan diagnosis penyebab kematian pada kolom yang disediakan maka penyebab kematian tersebut sama dengan diagnosis utama pasien yaitu Stroke Hemoregik atau Stroke Non Hemoregik.

Rumah Sakit memiliki sertifikat kematian namun tidak ada format penulisan penyebab kematian. Format penulisan penyebab kematian tidak sesuai dengan yang telah ditentukan oleh WHO.

Keterangan diatas sesuai dengan hasil yang diungkapkan oleh dokter yang menangani kasus tersebut lewat wawancara. Hasil wawancara kepada dokter menunjukkan bahwa penulisan diagnosis penyebab kematian tidak dituliskan pada sertifikat kematian dan hanya ditulis pada lembar resume pasien keluar. Hal ini menyebaban tidak terlaksananya pelaporan data kematian yaitu RL4, karena sumber pelaporan $\mathrm{RL} 4$ adalah dari data pada sertifikat kematian.

Wawancara terhadap informan 1 menyatakan bahwa:

$$
\begin{aligned}
& \text { "di resume iya, kalau di sertikat } \\
& \text { kematian sih engga biasanya" } \\
& \text { (Informan 1) }
\end{aligned}
$$

Kemudian dari hasil observasi pada resume pasien keluar terdapat beberapa penyebab kematian yang tidak dicantumkan pada resume pasien keluar, dikarenakan penyebab kematian tersebut ialah diagnosis utama pada resume pasien keluar. Hal ini diperkuat lagi dari hasil wawancara dengan dokter yang menangangani kasus tersebut lewat wawancara, yaitu:

"ya karena penyebab kematian tersebut ialah stroke itu sendiri" (Informan 2)

Hasil wawancara menunjukkan bahwa, dokter menjelaskan jika tidak adanya penulisan diagnosis utama penyebab kematian maka yang menjadi penyebab kematian pasien adalah diagnosis utama pada resume pasien keluar yaitu stroke hemoregik atau stroke non hemoregik.

Dalam menentukan penyebab kematian dokter melihat dari data-data klinis 
seperti yang diungkapkan pada wawancara, yaitu:

"kalau menentukan penyebab kematian ya dilihat pada tanda-tanda herniasi otak ya berupa data-data klinis maupun pada pemeriksaan diliihat pada tanda-tanda pupil dan sebagainya" (Informan 3)

Hasil wawancara menunjukkan bahwa dokter dalam menentukan penyebab kematian pasien dilihat pada tanda-tanda herniasi otak atau dilihat pada data-data klinis pasien, yang kemudian dituliskan pada resume pasien keluar.

Pada hasil observasi penulisan diagnosis penyakit pasien, ada perbedaan penulisan nama diagnosis dengan penulisan diagnosis pada ICD. Hal ini diperjelas dengan yang diungkapkan dokter pada saat wawancara, yaitu:

"em belum, kami masih menggunakan istilah" (Informan 4)

Hasil wawancara menunjukkan bahwa penulisan diagnosis penyakit pasien masih menggunakan istilah-istilah yang digunakan atau singkatan-singkatan yang diberikan oleh dokter.

Berdasarkan uraian diatas dapat disimpulkan bahwa penulisan diagnosis penyebab utama kematian tidak dituliskan pada sertifikat kematian dan hanya ditulis pada lembar resume pasien keluar. Hal ini menyebaban tidak terlaksananya pelaporan data kematian yaitu RL4 karena sumber pelaporan $\mathrm{RL} 4$ adalah dari data pada sertifikat kematian. Dalam hal penulisan tidak semua diagnosis penyebab kematian dituliskan oleh dokter pada resume pasien keluar karena diagnosis utama tersebut sama dengan penyebab kematian pada pasien. Dalam menentukan penyebab kematian, dokter melihat pada data klinis pasien yang kemudian dituliskan pada resume pasien keluar, penulisan diagnosis masih menggunakan istilah contohnya dalam penulisan diagnosis utama $\mathrm{SNH}$ (Stroke Non Haemorraghic) yang diberikan kode oleh koder dengan kode 164 padahal jika ditinjau lagi menggunakan ICD-10 kode 164 adalah untuk diagnosis CVA (Cerebrovascular Accident) dan seharusnya $\mathrm{SNH}$ yang disesuaikan dengan ICD-10 adalah 163.9 yaitu Cerebral Infarction, hal inilah yang menyebabkan ketidaktepatan dalam diagnosis.

\section{Prosedur Pelaksanaan Penentuan Kodefikasi Penyebab Kematian}

Berdasarkan hasil observasi didapat tidak ada pedoman tertulis (SOP) dalam menentukan kode penyebab kematian atau mortalitas. Petugas koder hanya melakukan kodefikasi untuk kasus morbiditas berdasarkan SOP tentang Coding menggunakan ICD-10, sehingga petugas koder hanya memilih diagnosis utama dan diagnosis sekunder pasien yang telah dituliskan oleh dokter pada lembar resume pasien keluar, akan tetapi dokter juga menuliskan penyebab kematian pada resume pasien keluar, namun tidak dilakukan nya pengkodean pada penyebab kematian.

Keterangan diatas sesuai dengan hasil wawancara dengan Kepala instalasi rekam medis mengenai prosedur penyebab kematian, yaitu:

"kalau SOP tentang kode kematian kadada yang ada kode yang umum haja" (Kalau SOP mengenai kode kematiian tidak ada yang ada hanya kode tentang morbiditas) (Informan 5)

Hasil wawancara didapat bahwa SOP (Standar Operasional Prosedur) mengenai pelaksanaan penyebab kematian tidak ada, sehingga tidak dilaksanakan nya penyebab kematian. Rumah sakit hanya memiliki SOP untuk kasus morbiditas atau bisa disebut secara umum yaitu kode untuk diagnosis utama dan sekunder.

Dan didukung lagi oleh informan selanjutnya mengenai pelaksanaan penyebab kematian, bahwa penyebab kematian memang tidak dilaksanakan, yaitu:

"tidak pernah dikerjakan kerena tidak adanya SOP" (Informan 6)

Berdasarkan uraian diatas bahwa petugas koder tidak pernah melakukan diagnosis utama penyebab kematian karena tidak adanya SOP atau kebijakan mengenai pelaksanaannya, sehingga petugas koder hanya melakukan diagnosis kasus morbiditas. RSUD Brigjend $\mathrm{H}$. Hassan Basry Kandangan memiliki SOP coding sebagai berikut : Menerima penyetoran rekam medis Rawat jalan dan Rawat inap, Membuka aplikasi SIM-RS, Klik berkas $\rightarrow$ data $\rightarrow$ data pasien, Masukkan No.RM klik tombol cari, Setelah No.RM yang ingin di coding keluar, klik periksa diagnosa, diagnosa atau tindakan dapat dibaca dengan jelas oleh 
petuga coding untuk memperlancar proses pengklasifikasikan kode diagnose atau tindakan, Menentukan jenis diagnose (diagnosa utama atau diagnosa sekunder 1, diagnose sekunder 2 , diagnose sekunder 3 ), Pemberian kode diagnose sesuai dengan ICD-10. Jika pasien mendapatkan tindakan medis, maka pilih jenis diagnose tindakan, pemberian kode tindakan sesuai dengan ICD-9 CM 10. Setelah pemberian kode diagnose atau tindakan selesai, klik tombol simpan yang ada di Aplikasi SIM-RS.

Penulisaan kodefikasi diagnosis penyakit tidak dituliskan pada lembar resume medis maupun resume pasien keluar, petugas hanya menuliskan kodefikasi diagnosis pasien pada komputer. Penulisan kodefikasi pada diagnosis sekunder tidak semua dilakukan contohnya pada kasus pasien Stroke hemoregik dengan diagnosis sekunder Hipertensi, $\mathrm{ICH}$, Hydrochepalus, acute respiratory koder hanya melakukan pengkodean diagnosis hipertensi dengan kode diagnosis utama 160 dan diagnosis sekunder I10.

Berdasarkan wawancara dapat diambil kesimpulan bahwa SOP (Standar Operasional Proseedur) mengenai pelaksanaan penyebab kematian tidak ada, sehingga tidak dilaksanakannya penyebab kematian. Rumah sakit hanya memiliki SOP untuk kasus morbiditas atau bisa disebut Tabel 2 Kode Diagnosis Utama di RSUD Brigjend H. Hasan Basry Kandangan

\begin{tabular}{|c|c|c|c|c|c|c|}
\hline \multirow{2}{*}{$\begin{array}{l}\text { Jumlah } \\
\text { sampel }\end{array}$} & \multirow{2}{*}{$\begin{array}{l}\text { Diagnosis } \\
\text { Utama }\end{array}$} & \multirow{2}{*}{$\begin{array}{c}\text { Kode } \\
\text { petugas }\end{array}$} & \multirow{2}{*}{$\begin{array}{c}\text { Kode } \\
\text { peneliti }\end{array}$} & \multicolumn{2}{|c|}{$\begin{array}{l}\text { Ketepatan } \\
\text { kode }\end{array}$} & \multirow[t]{2}{*}{ Keterangan } \\
\hline & & & & $\mathbf{T}$ & TT & \\
\hline 17 & $\begin{array}{l}\text { Stroke Non } \\
\text { Hemoregik }\end{array}$ & 164 & 163.9 & & 1 & $\begin{array}{c}\text { Stroke non hemoregik disebabkkan oleh } \\
\text { sumbatan otak sedangkan untuk kode } \\
\text { diagnosis } 164 \text { adalah untuk } \\
\text { Cerebrovascular Accident }\end{array}$ \\
\hline 51 & $\begin{array}{c}\text { Stroke } \\
\text { Hemoregik }\end{array}$ & 160 & 161.9 & & 1 & $\begin{array}{c}\text { Stroke hemoregik/ intracerebral } \\
\text { hemmorrhagae disebabkan oleh } \\
\text { pecahnya pembuluh darah sedangkan } \\
\text { untuk kode diagnosis } 160 \text { adalah untuk } \\
\text { perdarahan subrakhnoid }\end{array}$ \\
\hline \multicolumn{7}{|c|}{ Total sampel 68} \\
\hline
\end{tabular}

Diagnosis utama yang diberikan koder belum tepat, karena jika ditinjau lagi menggunakan ICD-10 maka kode diagnosis SNH I63.9 dan untuk SH yaitu I61.9. secara umum yaitu kode untuk diagnosis utama dan sekunder, sehingga petugas koder hanya melakukan diagnosis kasus morbiditas.

\section{Ketepatan Kodefikasi Penyebab Utama Kematian}

Penyebab kematian yang ada di RSUD Brigjend H.Hasan Basry Kandangan ditentukan oleh dokter dengan melihat pada riwayat penyakit pasien/data klinis kemudian dokter menulis penyebab kematian pada resume pasien keluar.

Dari hasil observasi 68 dokumen rekam medis menunjukan bahwa penyebab kematian tidak diakukan oleh petugas koder, berikut sampel penulisan penyebab kematian pada resume pasien keluar di RSUD Brigjend H.Hasan Basry :

Tabel 1 Diagnosis Penyebab Kematian

\begin{tabular}{llc} 
Diagnosis Utama & : SH & 160 \\
\hline Diagnosis sekunder & $:$ HT & 110 \\
\hline Penyebab kematian & $\begin{array}{l}\text { :Herniasi } \\
\text { Otak }\end{array}$ & - \\
\hline
\end{tabular}

Disini koder hanya memberikan kode diagnosis utama 160 dan 110 sebagai diagnosis sekunder, untuk penyebab kematian tidak dilakukan . 


\begin{tabular}{|c|c|c|c|c|c|c|}
\hline \multirow{2}{*}{$\begin{array}{l}\text { Jumlah } \\
\text { kasus }\end{array}$} & \multirow{2}{*}{$\begin{array}{l}\text { Diagnosis } \\
\text { Sekunder }\end{array}$} & \multirow{2}{*}{$\begin{array}{c}\text { Kode } \\
\text { petugas }\end{array}$} & \multirow{2}{*}{$\begin{array}{l}\text { Kode } \\
\text { peneliti }\end{array}$} & \multicolumn{2}{|c|}{$\begin{array}{l}\text { Ketepatan } \\
\text { kode }\end{array}$} & \multirow[t]{2}{*}{ Keterangan } \\
\hline & & & & $\mathbf{T}$ & TT & \\
\hline 35 & Hipertensi & 110 & 110 & 1 & & $\begin{array}{l}\text { Kode diagnosis sudah sesuai } \\
\text { dengan ICD-10 }\end{array}$ \\
\hline 18 & Hemipara & G81.9 & G81.9 & 1 & & $\begin{array}{l}\text { Kode diagnosis sudah sesuai } \\
\text { dengan ICD-10 }\end{array}$ \\
\hline 5 & Henti nafas & - & J96.9 & & 1 & $\begin{array}{c}\text { Tidak dilakukan pengkodean oleh } \\
\text { petugas koder }\end{array}$ \\
\hline 4 & Pneumonia & J18.9 & J18.9 & 1 & & $\begin{array}{c}\text { Kode diagnosis sudah sesuai } \\
\text { dengan ICD-10 }\end{array}$ \\
\hline 3 & Hydrochepalus & - & G91.9 & & 1 & $\begin{array}{c}\text { Tidak dilakukan pengkodean oleh } \\
\text { petugas koder }\end{array}$ \\
\hline 1 & ADHF & - & 150.9 & & 1 & $\begin{array}{c}\text { Tidak dilakukan pengkodean oleh } \\
\text { petugas koder }\end{array}$ \\
\hline 4 & DM & E14 & E14 & 1 & & $\begin{array}{c}\text { Kode diagnosis sudah sesuai } \\
\text { dengan ICD-10 }\end{array}$ \\
\hline 5 & Stres ulcer & - & K25 & & 1 & $\begin{array}{c}\text { Tidak dilakukan pengkodean oleh } \\
\text { petugas koder }\end{array}$ \\
\hline 2 & Epileptikus & G40.9 & G40.9 & 1 & & $\begin{array}{c}\text { Kode diagnosis sudah sesuai } \\
\text { dengan ICD-10 }\end{array}$ \\
\hline 1 & Dysphagia & $\mathrm{R} 13$ & $\mathrm{R} 13$ & 1 & & $\begin{array}{c}\text { Kode diagnosis sudah sesuai } \\
\text { dengan ICD-10 }\end{array}$ \\
\hline 1 & SOL & - & R90.0 & & 1 & $\begin{array}{c}\text { Tidak dilakukan pengkodean oleh } \\
\text { petugas koder }\end{array}$ \\
\hline 2 & ISK & N39.0 & N39.0 & 1 & & $\begin{array}{l}\text { Kode diagnosis sudah sesuai } \\
\text { dengan ICD-10 }\end{array}$ \\
\hline 1 & Cardiac arrest & - & 146.9 & & 1 & $\begin{array}{c}\text { Tidak dilakukan pengkodean oleh } \\
\text { petugas koder }\end{array}$ \\
\hline 1 & Hiperglikemia & - & R73.9 & & 1 & $\begin{array}{l}\text { Tidak dilakukan pengkodean oleh } \\
\text { petugas koder }\end{array}$ \\
\hline 4 & Syok sepsis & - & A41.9 & & 1 & $\begin{array}{c}\text { Tidak dilakukan pengkodean oleh } \\
\text { petugas koder }\end{array}$ \\
\hline 1 & Asma & J45.9 & $\mathrm{J} 45.9$ & 1 & & $\begin{array}{c}\text { Tidak dilakukan pengkodean oleh } \\
\text { petugas koder }\end{array}$ \\
\hline 1 & Vertigo & $\mathrm{R} 42$ & $\mathrm{R} 42$ & 1 & & $\begin{array}{l}\text { Tidak dilakukan pengkodean oleh } \\
\text { petugas koder }\end{array}$ \\
\hline
\end{tabular}

Kendala dalam Pelaksanaan Kodefikasi

Dalam pelaksanaan penyebab utama kematian di RSUD Brigjend H.Hasan Basry Kandangan ditemukan oleh peneliti terdapat hambatan sebagai berikut :

\section{Sumber Daya Manusia (SDM)}

Sumber daya manusia diantaranya adalah dokter, dalam resume medis pasien keluar ada sebagian diagnosis penyebab kematian tidak di cantumkan di resume pasien keluar pada kolom penyebab kematian oleh dokter dan dalam hal penulisan diagnosis dokter memiliki singkatan-singkatan yang kurang dapat di pahami oleh koder.

Keterangan diatas sesuai dari hasil wawancara kepada petugas koder mengenai apa saja yang menjadi kendala dalam

"tulisan dokter bahanu kada jelas lawan jua sapalih ada yang kada beisi, diagnosa nya kada jelas jadi mencari di asuhan keperawatan atau catatan perkembangan" (Tulisan dokter yang kurang jelas dan ada sebagian diagnosis yang tidak diisi, kalau penulisan tiidak jelas maka dilihat pada asuhan keperawatan atau catatan perkembangan). (Informan 7) wawancara kepada koder menunjukkan bahwa ketepatan juga dipengaruhi oleh penulisan diagnosis yang kurang dapat dipahami oleh petugas koder karena dokter memiliki singkatan-singkatan penulisan diagnosis dan ada beberapa diagnosis yang kurang lengkap dalam 
penulisan di resume pasien keluar. Koder akan melihat pada asuhan keperawatan atau catatan perkembangan sebagai acuan untuk melakukkan diagnosis penyakit pasien.

\section{Kebijakan}

Di RSUD Brigjend H.hasan Basry Kandangan tidak memiliki kebijakan atau protap tentang koding maupun prosedur mengkoding dalam pelaksanaan penyebab kematian.

Keterangan diatas diperkuat dengan hasil wawancara dengan kepala instalasi rekam medis mengenai prosedur penyebab kematian, yaitu

"kalau SOP tentang kode kematian kadada yang ada kode yang umum haja" (KalauSOP mengenai kode kematiian tidak ada yang ada hanya kode tentang morbiditas). (Informan 8)

Hasil wawancara kepada kepala rekam medis bahwa SOP (Standar Operasional Prosedur) mengenai pelaksanaan penyebab kematian tidak ada, sehingga tidak dilaksanakan nya penyebab kematian. Rumah sakit hanya memiliki SOP untuk kasus morbiditas atau bisa disebut secara umum yaitu kode unntuk diagnosis utama dan sekunder.

Kompetensi

Berdasarkan hasil penelitian didapat bahwa koder adalah lulusan DIII Rekam Medis namun tidak menggunakan aturan kode mortalitas karena tidak adanya kebijakkan berupa SOP. Keterangan mengenai SOP sesuai dengan hasil wawancara pada petugas koder

"tidak pernah dikerjakan kerena tidak adanya SOP" (Informan 9).

Berdasarkan uraian diatas bahwa tidak pernah melakukan diagnosis utama penyebab kematian karena tidak adanya SOP atau kebijakan mengenai pelaksanaannya, sehingga petugas koder hanya melakukan diagnosis kasus morbiditas.

Terkait dengan pelatihan sesuai dengan mortalitas MMDS koder di RSUD Brigjend H.hasan Basry Kandangan belum pernah mengikuti pelatihan pengkodean pada kasus kematian di lingkungan Rumah Sakit maupun luar Rumah Sakit.

Keterangan diatas sesuai dengan hasil wawancara dengan petugas koder mengenai pelatihan pengkodean pada kasus kematian

"tidak pernah, yang ada kodefikasi mengenai koding dasar saja atau koding morbiditas)".(Informan 10)

Berdasarkan uraian diatas bahwa petugas koder belum pernah mengikuti pelatihan diagnosis utama penyebab kematian dan hanya mengikuti pelatihan diagnosis untuk kasus morbiditas.

\section{Pembahasan}

Prosedur Pelaksanaan penentuan ketepatan kode penyebab utama kematian

\section{Prosedur Penentuan Penyebab Kematian}

Dari hasil penelitian mengenai prosedur dalam menentukan penyebab kematian di RSUD Brigjend H. Hasan Basry Kandangan belum diilaksanakan karena tidak adanya penulisan diagnosis penyebab kematian pada sertifikat kematian dan dokter hanya menuliskan diagnosis penyebab kematian pada resume pasien keluar. Pada sertifikat kematian juga tidak ada kolom penulisan diagnosis penyebab kematian pada sertifikat kematian yang sesuai dengan peraturan $\mathrm{WHO}$.

Penulisaan pada sertifikat kematian harus dilakukan, karena menurut WHO data mortalitas merupakan sumber utama yang digunakan sebagai dasar pembuatan laporan penyebab kematian. Laporan penyebab kematian sangatlah berguna agar rumah sakit dapat membuat klasifikasi tentang penyebab kematian utama yang dapat digunakan untuk evaluasi kualitas pelayanan, kebutuhan tenaga medis dan alat-alat medis (7).

Dalam penulisan diagnosis penyebab kematian pada sertifikat kematian, memiliki peraturan mortalitas yang mengharuskan dokter untuk melihat semua penyakit yang diderita pasien dan keadaan pasien yang mengalami kecelakaan atau cedera yang membuat pasien tersebut meninggal, setelah itu dokter menuliskan sebab kematian seorang pasien pada lembar sertifikat kematian dengan urutan I penyebab langsung yaitu penyakit atau kondisi langsung menuju kematian, penyebab antara yaitu penyakit yang mengakibatkan penyebab diatasnya, dan penyebab dasar merupakan awal dari rangkaian di atasnya (7) 
Hasil penelitian didapat bahwa penulisan diagnosis penyebab kematian di RSUD Brigjend $\mathrm{H}$. Hasan Basry Kandangan belum sesuai dengan teori dimana penulisan diagnosis penyebab kematian tidak dituliskan pada sertifikat kematian dengan urutan penyebab langsung, penyebab antara dan penyebab dasar.

Dalam menetapkan alur sebab kematian di RS St. Elisabeth Semarang tidak berpedoman pada Standar Operasional Prosedur karena di RS St. Elisabeth tidak memiliki Standar Operasional Prosedur dalam menentukan sebab kematian, akan tetapi pada saat menentukan sebab kematian seorang pasien, dokter berpedoman pada ICD 10 volume 2 atau dasar yang digunakan dokter dalam menentukan kode sebab kematian adalah ICD 10 volume 2 (8).

\section{Prosedur Pelaksanaan Penentuan Kodefikasi Penyebab Kematian}

Dari hasil penelitian mengenai pelaksanaan penentuan kodefikasi dalam menentukan penyebab kematian di RSUD Brigjend H.Hasan Basry Kandangan tidak memiliki SOP mengenai penyebab kematian sehingga petugas koder tidak melaksanakan penyebab kematian/mortalitas. Petugas koder hanya melakukan kodefikasi kasus kesakitan/morbiditas pada pasien.

Penyebab kematian harus melihat beberapa peraturan mortalitas dengan menggunakan rule seleksi yang dilihat pada sertifikat kematian. Data mortalitas sangat bergantung pada sertifikat kematian sebagai sumber utama data kematian. Pengisian sertifikat kematian akan memasukan urutan kejadian yang menyebabkan kematian pada sertifikat kematian dengan format Internasional. Kemudian dilakukan pengecekan melalui tabel bantu MMDS sebagai alat cross-check untuk penegakkan diagnosis penyebab kematian. Penyebab kematian sangat penting sebagai landasan menyusun program preventif primer, sehingga status kesehatan masyarakat menjadi lebih baik. Sertifikat kematian juga berfungsi sebagai pendukung dalam permohonan asuransi, sebagai pedoman atau alat untuk memudahkan pencarian apabila dilain waktu ada keluarga yang meminta sertifikat kematian dan sebagai pelaporan RL4

Di RSUD Brigjend $\mathrm{H}$. Hasan Basry Kandangan pemberian kode diagnosis stroke pada kasus kematian, belum sesuai dengan peraturan mortalitas dimana tidak adanya pencantuman diagnosis pada sertifikat kematian dan petugas koder hanya memberikan kode pada diagnosis utama dan diagnosis sekunder pada resume pasien keluar. Tidak adanya pemberian kode diagnosis penyebab kematian menyebabkan Rumah Sakit tidak melaksanakan pelaporan data kematian (RL4). Padahal pelaporan RL4 dikirim ke DirJen YanMed DepKes RI untuk Arsip rumah sakit dan berguna sebagai : Membantu mewujudkan visi dan misi RS, Membangun dan mengembangkan infrastruktur teknologi informasi, Mensosialisasikan dan meningkatkan kemampuan sumber daya manusia RS mengoperasikan teknologi informasi, Meningkatkan kinerja Rumah Sakit menjadi lebih efisien dan efektif, Meningkatkan nilai jual Rumah Sakit di masyarakat sebagai RS yang mengedepankan pelayanan, Manajemen pengelolaan data menjadi informasi yang cepat dan tepat guna bagi kepentingan user, Manajemen maupun Pemerintah, Meningkatkan mutu dan mempercepat proses pelayanan RS, Meningkatkan loyalitas dan kebanggaan karyawan terhadap Rumah Sakit tempat mereka mengabdi, Mengurangi kesalahankesalahan faktor manusia, Menghilangkan permasalahan redudansi data, Menghilangkan permasalahan ketidakkonsistenan data, Pemetaan desain sistem informasi sesuai dengan kebutuhan informasi pada saat ini dan masa datang.

Penggunaan tabel MMDS sangat penting karena tabel tersebut dipakai oleh banyak negara untuk melakukan proses penyebab kematian bahkan di Indonesia sendiri telah mengembangkan pencatatan sertifikat kematian menggunakan alat bantu tabel MMDS hal tersebut dikembangkan oleh Badan Penelitian dan Pengembangan Kesehatan Kementrian Kesehatan RI.

\section{Ketepatan dan Penentuan Kode Diagnosis \\ a. Penentuan Kodefikasi Penyebab Kematian}


Berdasarkan penelitian ini kode diagnosis penyebab utama kematian pada kasus stroke di RSUD Brigjend $\mathrm{H}$. Hasan Basry Kandangan tidak tepat, karena tidak adanya penyebab kematian. Dalam melakukan penyebab kematian dilakukan langkah-langkah berikut:

Dokter menuliskkan penyebab kematian pada resume medis pasien keluar dengan penulisan,

Diagnosis utama : $\mathrm{SH}$

Diagnosis sekunder : HT

Penyebab kematian : :Herniasi otak

Maka dipilih penyebab langsung yaitu Herniasi otak dengan kode G93.5 dengan penyebab antara dari penyebab langsung $\mathrm{SH}$ dengan kode $\mathrm{I} 61.9$ dan penyebab antara dari stroke adalah HT dengan kode 110 . Kemudian dilakuan cek menggunakan tabel MMDS, yaitu dilihat pada tabel $D$ dengan menerapkan Rule Seleksi 1.

Langkah pertama, menentukan untuk menemukan penyebab asal kondisi langsung pada penyebab kematian resume pasien keluar, jadi apakah SH (I61.9) menyebabkan herniasi otak (G93.5)---G819--I600-1709 sub-addres (rentang kode, mencakup 161.9)

Diketahui herniasi otak bisa disebabkan oleh SH (I61.9) karena 161.9 ada dalam rentang kode 1600-1709.

Langkah kedua, memeriksa apakah HT dapat menyebabkan SH---1618-1620--I00-I150 sub-addres (rentang kode, mencakup I60). HT (I10) dapat menyebabkan SH (I61.9)

Rule 1 menyatakan bahwa : Jika ada lebih dari satu urutan yang berakhir dengan kondisi yang pertama disebutkan, pilihlah penyebab asal dari urutan yang pertama disebutkan.

Karena HT penyebab asal dari urutan pertama (penyebab kematian yang dituliskan dokter pada resume pasien keluar) yang berakhir dengan kondisi yang pertama disebutkan, maka penyebab kematian nya adalah HT (Hipertensi) I10.

Kode diagnosis utama pada kasus Stroke, berikut penentuan kode diagnosis utama pada kasus stroke di RSUD Brigjen $\mathrm{H}$. Hasan Basry Kandangan :

1. Diagnosis pertama yaitu SNH (stroke non hemoregik) adalah gangguan peredaran darah pada otak yang dapat berupa penyumbatan pembuluh darah arteri, sehingga menimbulkan infark/ iskemik. Umumnya terjadi pada saat penderita istirahat. Tidak terjadi perdarahan dan kesadaran umumnya baik.

Di RSUD Brigjend $H$. Hasan Basry Kandangan petugas koder memberikan kode diagnosis Stroke non hemoregik adalah 164 yaitu Stroke, not specified as haemorrhage or infarction. Jia ditinjau menggunakan ICD-10 maka pengkodean untuk diagnosis Stroke Non hemoregik adalah 163.9 yaitu Cerebral Infarction, sedangkan kode 164 digunakan untuk kode diagnosis CVA (Cerebrovascular Accident).

2. Diagnosis kedua SH (Stroke hemoregik) atau Intracerebral hemmorrhage yaitu terjadinya pembuluh darah di otak pecah. Pecahnya pembuluh darah mengakibatkan darah mengalir ke rongga sekitar jaringan otak. Karena tidak menerima oksigen dan bahan makanan dari darah, sel-sel dan jaringan otak pun akan mati. Kematian jaringan otak akan terjadi dalam waktu 4 sampai 10 menit setelah penyediaan darah terhenti (11).

Di RSUD Brigjend $\mathrm{H}$. Hasan Basry Kandangan petugas koder memberikan kode diagnosis Stroke hemoregik dengan kode diagnosis 160 yaitu Subrachnoid haemorrhage. Jika ditinjau menggunakan ICD-10 maka pengkodean pada diagnosis Stroke hemoregik adalah 161.9 yaitu Intracrebral haemorrhage, sedangkan kode 160 adalah untuk kode diagnosis SAH (Subrachnoid haemorrhage).

b. Kode Diagnosis Sekunder Pada Kasus Stroke

Kemudian penentuan kode diagnosis sekunder pada kasus stroke di RSUD Brigjen $\mathrm{H}$. Hasan Basry Kandangan :

1. Hipertensi merupakan tekanan darah tinggi yaitu kekuatan aliran darah dari jantung yang mendorong melawan dinding pembuluh darah (arteri). Di RSUD Brigjend $\mathrm{H}$. Hasan Basry Kandangan pengkodean untuk diagnosis Hipertensi sudah sesuai dengan ICD-10 yaitu I10 Essential hypertension.

2. Hemipara atau hemiplegia merupakan suatu kondisi adanya kelemahan pada salah satu sisi tubuh atau ketidakmampuan untuk menggerakkan 
anggota tubuh pada satu sisi. Di RSUD Brigjend $\mathrm{H}$. Hasan Basry Kandangan pengkodean untuk diagnosis Himipara sudah sesuai dengan ICD-10 yaitu G81.9 Hemiplegia.

3. Henti nafas atau gagal nafas adalah suatu kegawatan yang disebabkan oleh gangguan pertukaran oksigen dan karbondioksida, sehingga sistem pernafasan tidak mampu memenuhi metabolisme tubuh. Di RSUD Brigjend $\mathrm{H}$. Hasan Basry Kandangan pengkodean untuk diagnosis sekunder Henti nafas tidak dilakukan oleh petugas koder. Peneliti memberikan kode pada diagnosis Henti Nafas sesuai dengan ICD-10 yaitu J96.9 Respiratory Failure, unspecified.

4. Pneumonia adalah peradangan yang terjadi di dalam jaringan paru-paru baik itu disalah satu paru-paru atau keduanya dikerenakan adanya infeksi. Di RSUD Brigjend $\mathrm{H}$. Hasan Basry Kandangan pengkodean untuk diagnosis Pneumonia sudah sesuai dengan ICD-10 yaitu J18.9 Pneumonia.

5. Hidrosefalus adalah penumpukan cairan pada rongga otak atau yang disebut dengan ventrikel, yang mengakibatkan ventrikel-ventrikel di dalamnya membesar dan menekan organ tersebut, tekanan ini dapat merusak jaringan dan melemahkan fungsi otak. Di RSUD Brigjend $H$. Hasan Basry Kandangan pengkodean untuk diagnosis sekunder Hydrochepalus tidak dilakukan oleh petugas koder. Peneliti memberikan kode pada diagnosis Hydrochepalus sesuai dengan ICD-10 yaitu G91.9 Hydrochepalus.

6. ADHF (Acute Decompensated Heart Failure) merupakan gagal jantung akut yang didefinisikan sebagai serangan yang cepat (rapid onset) dari gejalagejala atau tanda-tanda akibat fungsi jantung yang abnormal. Di RSUD Brigjend $\mathrm{H}$. Hasan Basry Kandangan pengkodean untuk diagnosis sekunder $A D H F$ tidak dilakukan oleh petugas koder. Peneliti memberikan kode pada diagnosis $A D H F$ sesuai dengan ICD-10 yaitu I50.9 Heart Failure

7. DM (Diabetes Melitus) adalah penyakit jangka panjang atau kronis yang ditandai dengan kadar gula darah (glukosa) yang jauh di atas normal. Di RSUD Brigjend $H$. Hasan Basry Kandangan pengkodean untuk diagnosis DM sudah sesuai dengan ICD-10 yaitu E14 Unspecified Diabetes Melitus.

8. Stress Ulcer atau tukak beban sebagai suatu sindroma yang ditandai dengan adanya perdarahan akut atau perforasi saluran cerna bagian atas akibat kerusakan mukosa pada pasien yang menderita penyakit kritis atau trauma yang berat. Di RSUD Brigjend $\mathrm{H}$. Hasan Basry Kandangan pengkodean untuk diagnosis sekunder Stress Ulcer tidak dilakukan oleh petugas koder. Peneliti memberikan kode pada diagnosis Stress Ulcer sesuai dengan ICD-10 yaitu K25 Gastric Ulcer.

9. Epileptikus adalah kondisi yang mempengaruhi otak dan menyebabkan kejang terjadi secara berulang. Kejang sendiri merupakan lonjakan listrik di otak yang terjadi secara mendadak. Di RSUD Brigjend $H$. Hasan Basry Kandangan pengkodean untuk diagnosis Epileptikus sudah sesuai dengan ICD-10 yaitu G40.9 Epilepsy, unspecified.

10. Disfagia adalah sebuah istilah medis yang artinya sulit menelan. Di RSUD Brigjend $\mathrm{H}$. Hasan Basry Kandangan pengkodean untuk diagnosis Disfagia sudah sesuai dengan ICD-10 yaitu R13 Dysphagia.

11. SOL (Space Occupying Lesion) merupakan generalisasi masalah tentang adanya lesi pada ruang intracranial khususnya yang mengenai otak. Di RSUD Brigjend H. Hasan Basry Kandangan pengkodean untuk diagnosis sekunder SOL tidak dilakukan oleh petugas koder. Peneliti memberikan kode pada diagnosis SOLsesuai dengan ICD-10 yaitu R90.0 Intracranial space-occupying lesion.

12. ISK (infeksi saluran kemih) adalah kondisi ketika organ yang termasuk ke dalam sistem kemih, yaitu ginjal, ureter, kandung kemih, dan uretra, mengalami infeksi. Di RSUD Brigjend $H$. Hasan Basry Kandangan pengkodean untuk diagnosis ISK sudah sesuai dengan 
ICD-10 yaitu N39.0 Urinary tract infection, site not specified.

13. Cardiac arrest atau henti jantung adalah kondisi di mana detak jantung berhenti secara tiba-tiba. Di RSUD Brigjend $\mathrm{H}$. Hasan Basry Kandangan pengkodean untuk diagnosis sekunder Cardiac arrest tidak dilakukan oleh petugas koder. Peneliti memberikan kode pada diagnosis Cardiac arrest sesuai dengan ICD-10 yaitu 146.9 Cardiac arrest.

14. Hiperglikemia adalah kurang spasi istilah medis yang menunjukkan terlalu banyak glukosa yang beredar dalam darah, dengan kata lain bisa kita sebut dengan gula darah tinggi. Di RSUD Brigjend $\mathrm{H}$. Hasan Basry Kandangan pengkodean untuk diagnosis sekunder Hiperglikemia tidak dilakukan oleh petugas koder. Peneliti memberikan kode pada diagnosis Hiperglikemia sesuai dengan ICD-10 yaitu R73.9 Hyperglycaemia.

15. Syok sepsis adalah suatu keadaan dimana tekanan darah turun sampai tingkat yang membahayakan nyawa sebagai akibat dari sepsis. Di RSUD Brigjend $\mathrm{H}$. Hasan Basry Kandangan pengkodean untuk diagnosis sekunder Syok sepsis tidak dilakukan oleh petugas koder. Peneliti memberikan kode pada diagnosis $\mathrm{H}$ Syok sepsis sesuai dengan ICD-10 yaitu A41.9 Sepsis, unspecified.

16. Asma adalah jenis penyakit jangka panjang atau kronis pada saluran pernapasan yang ditandai dengan peradangan dan penyempitan saluran napas yang menimbulkan sesak atau sulit bernapas. Di RSUD Brigjend $\mathrm{H}$. Hasan Basry Kandangan pengkodean untuk diagnosis Asma sudah sesuai dengan ICD-10 yaitu J45.9 Asthma, unspecified.

17. Vertigo adalah rasa berputar dan pusing saat seseorang berdiri atau bahkan duduk. Kondisi ini biasanya menandakan adanya gangguan keseimbangan. Di RSUD Brigjend $\mathrm{H}$. Hasan Basry Kandangan pengkodean untuk diagnosis Vertigo sudah sesuai dengan ICD-10 yaitu R42 Dizziness and giddines. c. Kendala dalam Pelaksanaan Kodefikasi

1. Sumber Daya Manusia

Di RSUD Brigjend H.Hasan Basry

Kandangan dalam penulisan diagnosis penyebab kematian ada beberapa yang tidak di cantumkan oleh dokter dan dalam hal penulisan diagnosis dokter memiliki singkatan-singkatan yang kurang dapat di pahami oleh koder. Hal inilah yang mempengaruhi ketidaktepatan koder dalam melakukan pengkodean akibatnya berpengaruh pada kelengkapan pelaporan data rumah sakit.

Tenaga medis (dokter) sebagai pemberi pelayanan utama pada seorang pasien bertanggung jawab atas kelengkapan dan kebenaran data dokumentasi, khususnya data klinik, yang tercantum dalam dokumen rekam medis. Data klinik berupa riwayat penyakit, hasil pemeriksaan, diagnosis, perintah pengobatan, laporan operasi atau prosedur lain merupakan input yang akan dikoding oleh petugas koding di bagian rekam medis.

\section{Kebijakan}

Di RSUD Brigjend H. Hassan Basry Kandangan kebijakan tertulis atau protap mengenai pengkodean penyebab kematian belum dicantumkan, padahal penyebab kematian digunakan sebagai laporan $R L 4$ (data morbiditas dan data mortalitas) adanya kebijakkan yang tertuang pada SOP maka akan mempermudah tenaga medis dalam pelaksanaannya sesuai dengan peraturan dan perundangan yang berlaku.

Standar operasional prosedur memberikan langkah yang benar dan terbaik berdasarkan konsensus bersama untuk melaksanakan berbagai kegiatan dan fungsi pelayanan yang dibuat oleh sarana pelayanan kesehatan berdasarkan standar profesi.

Bagian koding dan indeksing (K/I) adalah salah satu bagian dalam unit rekam medis. Dalam melaksanakan tugas pokoknya bagian ini memerlukan alat bantu meliputi : Buku ICD revisi ke 10 volume 1, volume 2 dan volume 3 untuk memastikan kode penyakit dan masalah kesehatan, Buku ICOPIM untuk memastikan kode operasi dan prosedur medis, Buku ID-O untuk memastikan kode penyakit kanker (kode ini dikhususkan untuk rumah sakit yang ditunjuk sebagai rumah sakit dengan pelayanan khusus kanker), Kamus 
kedokteran untuk menemukan arti istilahistilah kedokteran, Kamus bahasa Inggris untuk menemukan arti istilah-istilah dalam bahasa Inggris, Daftar kode ICD revisi ke 10 yang dibuat sendiri oleh bagian ini berdasarkan penyakit dan operasi yang sering ditulis oleh para dokter setelah dilakukan kolaborasi atau konsultasi dengan dokter-dokter yang bersangkutan.

Peran dan fungsinya sebagai pencatat dan peneliti kode penyakit dan diagnose yang ditulis dokter, kode operasi atau tindakan medis yang ditulis dokter atau petugas kesehatan lainnya, kode sebab kematian dari sebab kematian yang ditetapkan dokter. Serta mencatat dan menyimpan indeks penyakit, operasi atau tindakan medis, sebab kematian dan indeks dokter dan penyedia informasi nomor-nomor rekam medis yang memiliki jenis penyakit, operasi atau tindakan medis sebab kematian yang sama berdasarkan indeks yang bersangkutan untuk berbagai keperluan (misal audit medis, audit kematian dan audit keperawatan), serta pembuat laporan penyakit dan laporan kematian berdasarkan indeks penyakit, operasi dan sebab kematian (9).

3. Kompetensi

Petugas koder di RSUD Brigjend $\mathrm{H}$. Hasan Basry adalah lulusan DIII rekam medis ini sesuai dengan perundangundangan Menkes mengenai penyelenggaraan pekerjaan perekam medis. Dalam pelaksanaan pekerjaanya, perekam medis mempunyai kewenangan sesuai dengan kualifikasi pendidikan yaitu ahli madya rekam medis, yaitu : Melaksanakan kegiatan pelayanan pasien dalam manajemen dasar rekam medis dan informasi kesehatan, Melakukan evaluasi isi rekam medis, Melaksanakan sistem klasifikasi klinis dan kodefikasi penyakit yang berkaitan dengan kesehatan dan tindakan medis sesuai terminology medis yang benar, Melaksanakkan indeks dengan cara mengumpulkan data penyakit, kematian, tindakan dan dokter yang dikelompokkan pada indeks, Melaksanakan Sistem pelaporan dalam bentuk informasi kegiatan pelayanan kesehatan, Merancang struktur isi dan standar data kesehatan, untuk pengelolaan informasi kesehatan, Melaksanakan evaluasi kelengkapan isi diagnosis dan tindakan sebagai ketepatan pengkodean, Melaksanakan pengumpulan, validasi dan verifikasi data sesuai ilmu statistik Rumah Sakit .Melakukan pencatatan dan pelaporan surveilans, Mengelola kelompok kerja dan manajemen unit kerja dan menjalankan organisasi penyelenggara dan pemberi pelayanan kesehatan, Mensosialisasikan setiap program pelayanan rekam medis dan informasi kesehatan, Melaksanakan hubungan kerja sesuai kode etik profesi, Melakukan pengembangan diri terhadap kemajuan ilmu pengetahuan dan teknologi.

Terkait dengan pelatihan dalam pengkodean penyebab kematian belum sesuai dengan peraturan mortalitas MMDS karena koder di RSUD Brigjend H. Hasan Basry Kandangan belum pernah mengikuti pelatihan pengkodean pada kasus kematian dilingkungan Rumah sakit maupun luar Rumah sakit.

\section{Kesimpulan}

Tidak adanya Standar Operasional Prosedur mengenai kodefikasi penyebab utama kematian di RSUD Brigjend H.Hasan Basry Kandangan sehingga petugas koder tidak melaksanakan penyebab kematian yang berakibat pada tidak terlaksananya pelaporan RL4, RSUD Brigjend H.Hasan Basry Kandangan tidak melakukan penyebab kematian dan ketidaktepatan pada diagnosis utama yaitu Stroke, bahkan terdapat diagnosis sekunder yang tidak terisi seluruhnya hal ini menyebabkan pelaporan rumah sakit tidak akurat dan berpengaruh terhadap pembiayaan Ina-CBGs. Kendala yang mempengaruhi ketepatan penentuan kodefikasi kasus kematian berupa tidak adanya SOP untuk menentukan kodefikasi, tidak adanya pencantuman diagnosis pada sertifikat kematian dan tulisan dokter yang kurang dapat dipahami sehingga petugas koder akan kesulitan dalam melakukan diagnosis dan menyebabkan ketidaktepatan sebuah kodefikasi.

\section{Daftar Pustaka}

1. Departemen Kesehatan Republik Indonesia. (2013). Laporan Hasil Riset Kesehatan Dasar Indonesia (Riskesdas). Jakarta: Departemen Kesehatan Republik Indonesia 
2. Adams, Chair; Adams, Thomas Brott, Zoppo, Furlan, Goldstein, Robert, Higashida, Kidwell, Kwiatkowski, Marler, Hademenos (2003). Guidelines for Early Management of Patient With Ischemic Stroke (A Scientific Statement From the Stroke Council of the American Stroke Association). Pubmed. Stroke. Apr;34(4):1056-83.

3. Rozi (2013). Penderita Hipertansi di Kalimantan Selatan Tertinggi (https:// m.timesindonesia.co.id/read/143475/20 170302/094159/penderita-hiperte nsi-dikalsel-tertinggi-nasional/)(Diakses tanggal 12 Mei 2018)

4. Hatta, Gemala R (ed). (2014). Pedoman manajemen informasi kesehatan disarana pelayanan kesehatan. Edisi revisi 3. Jakarta: Universitas Indonesia Press.

5. Arifah. Siti. (2016). Tinjauan Pelaksanaan Pelaporan Data Mortalitas Pasien Rawat Inap di RSUD Wates. KTI. D3 Perekam Medis Dan Informasi Kesehatan. Sekolah Tinggi IImu Kesehatan Jenderal Achmad Yani Yogyakarta

6. Basuki, Sulistyo. 2010. Metode Penelitian. Jakarta : Penaku.

7. Depkes RI Dirjen Pelayanan Medik. 2006. Pedoman Pengelolaan Rekam Medis Rumah Sakit di Indonesia. Jakarta: Departemen Kesehatan RI Direktorat Jendral Pelayanan Medik.

8. Retnowati, Elisabet. 2017. Tinjauan ketepatan kode diagnose sebab kematian berdasarkan table medical mortality data sheet (MMDS) di RS St. Elisabeth Semarang. Skripsi. Fakultas Kesehatan Universitas Dian Nuswantoro. Semarang

9. Shofari, Bambang. 2018. Dasar Pengelolaan Rekam Medis dan Informasi Kesehatan. Semarang : Percetakan UDINUS.

10. Adib, M. 2009. Cara Mudah Memahami dan Menghindari Hipertensi, Jantung dan Stroke,Edisi ke-2. Yogyakarta: Dianloka Printika 